\title{
Oxidative behaviour of apomorphine and its metabolites
}

\author{
J.M.P.J. Garrido ${ }^{\text {a }}$, C. Delerue-Matos ${ }^{\text {a }}$, M.F.M. Borges ${ }^{\text {b }}$, T.R.A. Macedo ${ }^{\text {c }}$, \\ A.M. Oliveira-Brett ${ }^{\mathrm{d}, *}$ \\ ${ }^{a}$ CEQUP/Dep. Eng. Química, Instituto Superior de Engenharia do Porto, Rua S. Tomé, 4200-485 Porto, Portugal \\ ${ }^{\mathrm{b}}$ CEQOFFUP/Dep. Química Orgânica, Fac. Farmácia, Universidade do Porto, 4050-047 Porto, Portugal \\ ${ }^{\mathrm{c}}$ Fac. Medicina, Universidade de Coimbra, 3004-535 Coimbra, Portugal \\ ${ }^{\mathrm{d}}$ Dep. Química, Fac. Ciências e Tecnologia, Universidade de Coimbra, 3004-535 Coimbra, Portugal
}

Received 1 June 2001; received in revised form 15 October 2001; accepted 18 October 2001

\begin{abstract}
The metabolism of apomorphine is quite complex due to interactions with proteins and other tissue components that affect its pharmacokinetic profile. The electrochemical oxidation mechanism of apomorphine and of some synthesised apomorphine derivatives was studied. It was found to be related to the reaction of $o$-diphenol and tertiary amine groups and strongly dependent on pH. (C) 2002 Elsevier Science B.V. All rights reserved.
\end{abstract}

Keywords: Apomorphine; Oxidative behaviour; Electrochemistry

\section{Introduction}

Apomorphine is a drug used for a long time. It has recently received renewed attention because it was found to have beneficial effects in the treatment of idiopathic Parkinson's disease, a disease related with progressive degeneration of the central nervous system. However, the metabolism of apomorphine is quite complex mainly due to its catechol group, which after oxidation gives an electrophilic quinone that can interact with proteins and other tissue components, influencing the pharmacokinetic profile [1]. Furthermore, it is also stated that a change in the $N$-methyl group could result in a significant decrease in the affinities to $5-\mathrm{HT}_{1 \mathrm{~A}}$ receptors [2]. Thus, it is necessary to gain a better understanding of the metabolic and oxidative pathways of apomorphine. The oxidation behaviour of apomorphine, using a carbon paste electrode, identified oxoapomorphine as one oxidation product [3]. Since apomorphine metabolites could be involved in the coupling of nucleophilic groups on proteins [1], it was decided to synthesise some apomorphine derivatives in order to identify all the oxidation products.

\section{Experimental}

All experiments were performed using a 663 VA Metrohm system containing a glassy carbon working electrode $(d=2 \mathrm{~mm})$ (METROHM 6.1204.110), a glassy carbon rod counter electrode and an $\mathrm{Ag} / \mathrm{AgCl}$ reference electrode attached to an Autolab PSTAT 10 potentiostat/galvanostat running with model GPES version 3 software (EcoChimie, Netherlands).

The $\mathrm{pH}$ measurements were performed using a Metrohm E-520 pH-meter.

Apomorphine hydrochloride was obtained from Sigma and was used without further purification. Oxoapomorphine and diacetylapomorphine were synthesised [4]. All the other chemicals were of reagent grade and were used as received.

\section{Results and discussion}

The electrochemical oxidation behaviour of apomorphine and its oxidation products, oxoapomorphine and diacetylapomorphine, was studied over a wide $\mathrm{pH}$ range, between 1.2 and 12.0, at a glassy carbon working electrode using differential pulse voltammetry. The oxidation behaviour of apomorphine is strongly pH-dependent (Fig. 1). Up to $\mathrm{pH} 2$, only one anodic peak at $0.5 \mathrm{~V}$ vs. $\mathrm{Ag} / \mathrm{AgCl}$ was observed.

\footnotetext{
* Corresponding author. Tel./fax: +351-239-835295.

E-mail address: brett@ci.uc.pt (A.M. Oliveira-Brett).
} 


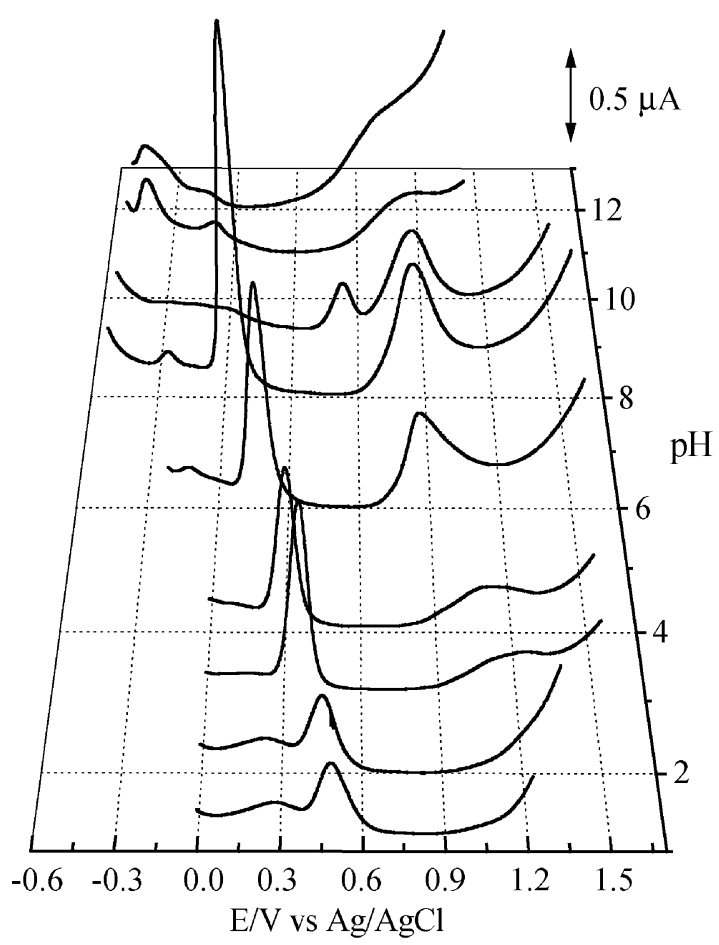

Fig. 1. 3D plot of differential pulse voltammograms of $100 \mu \mathrm{M}$ apomorphine as a function of $\mathrm{pH}$. Pulse amplitude $50 \mathrm{mV}$; scan rate 5 $\mathrm{mV} \mathrm{s}^{-1}$.

Between $\mathrm{pH} 2$ and $\mathrm{pH} 5$, two anodic waves, one near $0.3 \mathrm{~V}$ and the other at $1.1 \mathrm{~V}$, were observed. For $\mathrm{pH}>5$, three anodic peaks occurred at $-0.1,0.0$ and $0.8 \mathrm{~V}$. The potentials of apomorphine oxidation peaks shifted toward more positive values for lower $\mathrm{pH}$. Variation of the anodic peak potentials, $E_{\mathrm{p}}$, with $\mathrm{pH}$, for all the peaks, is linear with slopes $-55,-67$ and $-78 \mathrm{mV} / \mathrm{pH}$, respectively. The results obtained for apomorphine were compared with those obtained for oxoapomorphine and diacetylapomorphine and enabled an oxidation mechanism for apomorphine to be proposed. The anodic peak observed near $0.3 \mathrm{~V}$ vs. $\mathrm{Ag} /$
$\mathrm{AgCl}$ at low $\mathrm{pH}$, corresponding to another oxidation step related to the catechol group, does not occur for oxoapomorphine and diacetylapomorphine. Above $\mathrm{pH}$ 6, the small peak appearing at $-0.1 \mathrm{~V}$ vs. $\mathrm{Ag} / \mathrm{AgCl}$ also occurs for oxoapomorphine, leading to the conclusion that it corresponds to another oxidation step related to the o-quinone group. This is in agreement with previous conclusions that in aqueous solution, apomorphine rapidly undergoes spontaneous oxidative decomposition, this process being catalysed by oxygen and high $\mathrm{pH}$ [3]. Finally, the appearance of only one anodic peak for diacetylapomorphine at $+1.0 \mathrm{~V}$ leads to the conclusion that at this potential the oxidation of the apomorphine tertiary amine group occurs.

\section{Conclusions}

The electrochemical oxidation mechanism of apomorphine in aqueous solution is complex and strongly $\mathrm{pH}$ dependent. It was possible, through synthesis of the derivatives, to identify all the anodic peaks of apomorphine. This could lead to important advances in understanding its biological interactions since the oxidation products may play a very significant role in its pharmacokinetics.

\section{References}

[1] R.V. Smith, R.B. Velagapudi, A.M. McLean, R.E. Wilcox, Interactions of apomorphine with serum and tissue proteins, J. Med. Chem. 28 (1985) 613-620.

[2] M.H. Hedberg, J.M. Jansen, G. Nordvall, S. Hjorth, L. Unelius, A.M. Johansson, 10-substituted 11-oxygenated $(R)$-aporphines: synthesis, pharmacology, and modeling of $5-\mathrm{HT}_{1 \mathrm{~A}}$ receptor interactions, J. Med. Chem. 39 (1996) 3491-3502.

[3] H.-Y. Cheng, E. Strope, R.N. Adams, Electrochemical studies of the oxidation pathways of apomorphine, Anal. Chem. 51 (1979) $2243-$ 2246.

[4] H.H.A. Linde, M.S. Ragab, Die Autoxydation des Apomorphins, Helv. Chim. Acta 51 (1968) 683-687. 